\title{
Psykiatri: IMR-metoden legger vekt på menneskets ressurser
}

\section{Brukere og ansatte har sammen funnet ut av hvordan metoden Individuell mestring og tilfriskning (IMR) skal brukes i behandlingen på Seksjon for tidlig psykosebehandling ved Oslo universitetssykehus.}

Andreas Seierstad

Fag- og kvalitetsrådgiver

Seksjon for tidlig psykosebehandling, Oslo universitetssykehus

Ann Levin

Spesialvernepleier

Seksjon for tidlig psykosebehandling, Oslo universitetssykehus

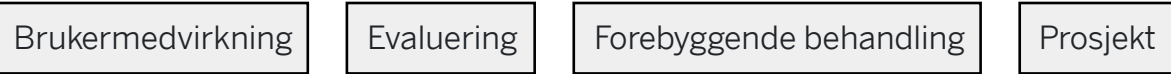

\section{Hovedbudskap}

Individuell mestring og tilfriskning (IMR) er en evidensbasert metode som brukes til å behandle mennesker med en alvorlig psykisk lidelse. Metoden skal gi brukerne håp om at de kan bli friskere. Individuell mestring og tilfriskning har et menneskesyn som legger vekt på menneskets egne ressurser, og den enkeltes vekst står sentralt.

Artikkelen beskriver et vellykket implementeringsprosjekt hvor utøverne aktivt påvirket hvordan intervensjonen ble tatt i bruk gjennom såkalt «bottom up»-stategi. 
På Seksjon for tidlig psykosebehandling ved Oslo universitetssykehus (OUS) tilbyr vi et standardisert kunnskapsbasert behandlingsprogram som legger vekt på individuell mestring og tilfriskning (IMR). Behandlingen benytter pedagogiske prinsipper (psykoedukativ) i intervensjonene for at brukerne skal bli friskere. Tiltakene blir iverksatt i tett samarbeid mellom hjelpere, brukere og ledere.

Over 200 sesjoner har blitt gjennomført ved seksjonen siden oppstarten høsten 2018. Implementeringsprosessen har vært preget av «bottom up»-tenkning der utøverne av metoden er aktivt deltakende i hvordan metoden blir tatt i bruk. Og der vi legger vekt på brukerens og hjelperens autonomi. I denne artikkelen deler vi erfaringer fra dette arbeidet.

\section{Behandlingen skal gi bedre livskvalitet}

Individuell mestring og tilfriskning, fra engelsk «Illness management and recovery» (IMR), er en strukturert og evidensbasert metode for mestring av alvorlige psykiske lidelser. IMR-behandlingen er basert på opplæring i flere kunnskapsbaserte metoder, som skal bidra til å gi håp og økt livskvalitet ved å fremme mestring og redusere tilbakefall.

Behandlingen tar utgangspunkt i brukernes egne mål og mestringsstrategier, for å fremme den enkeltes tilfriskning. Manualen for IMR, oversatt til norsk, er gjort tilgjengelig av IMR-nettverket i Norge (1).

\section{Metoden kombinerer ulike arbeidsformer}

Metoden er basert på en gjennomgang av 40 ulike randomiserte kontrollerte studier på mestring av sykdom hos mennesker med alvorlige psykiske lidelser, gjennomført av Mueser og medarbeidere (2). Studien fant fem virksomme komponenter for sykdomsmestring hos mennesker med alvorlig psykisk lidelse: psykoedukasjon, hjelp til hensiktsmessig medisinbruk, tilbakefallsforebygging, symptommestring og sosial trening.

Metoden følger en fast struktur med moduler for ulike temaer og kombinerer ulike arbeidsformer som undervisning, felles refleksjon, avkrysningsoppgaver og hjemmeoppgaver. IMR kan gis individuelt eller i grupper. En sesjon varer vanligvis en time (3). 


\section{Bakgrunn}

Ved Seksjon for tidlig psykosebehandling tilbyr vi psykoedukasjon i strukturert form, for å bidra til brukernes tilfriskningsprosesser. Vi arbeider ut fra en forståelse av at kunnskap om psykisk helse er viktig for å kunne mestre egen psykisk helse og uhelse. Også i nasjonale retningslinjer for psykosebehandling (4) vises det til at om retten til brukermedvirkning skal være reell må den enkelte bruker få tilpasset og tilstrekkelig informasjon om egen helsetilstand.

\section{Psykoedukasjon hjelper brukeren til å mestre egen lidelse}

Psykoedukasjon er derfor både et verktøy for å hjelpe brukeren til å mestre egen lidelse, men også en måte å overføre makt tilbake til brukeren. Vi ser psykoedukasjon som en viktig del av tilfriskningsorientert praksis.

Tilfriskningsorientert praksis er et begrep, som kan tolkes ulikt (5).

I det aktuelle prosjektet legger vi i begrepet tilfriskningsorientert praksis, en arbeidsmåte hvor vi ønsker å st $\varnothing$ tte brukernes tilfriskning ved å være lydhøre og vise lojalitet for deres egne ønsker for livet, samt ved å tilføre brukerne kunnskap om egen psykisk helse.

\section{Hva er psykoedukativ behandling?}

Psykoedukativ behandling er behandling av psykiske lidelser ved hjelp av pedagogiske prinsipper.

Psykoedukasjon er et tilbud om systematisk, strukturert og didaktisk informasjon om psykiske lidelser og deres behandling. Gjennom psykoedukasjon lærer pasienten og pårørende om lidelsen, og hvordan mestre denne bedre.

Kilder: Store Norske leksikon og Helsebiblioteket

\section{Gjennomføring av prosjektet}

Høsten 2018 ble IMR prøvd ut i prosjektform ved Seksjon for tidlig psykosebehandling. Tre prosjektdeltakere, to spesialsykepleiere og en spesialvernepleier ble sendt på kurs i metoden ved Crux Bergfløtt behandlingssenter. Deltakerne mottok regelmessig veiledning fra Crux Bergfløtt i de påfølgende 12 månedene. 


\section{Brukerne fikk tilbud om behandling}

Metoden ble tilbudt brukere som individuell behandling i

seksjonens døgnenhet og gruppebehandlingen i

poliklinikkens dagrehabilitering.

Individuell mestring og tilfriskning er en modulbasert metode hvor ulike moduler dekker ulike tema, for eksempel «bygge sosial støtte» eller «mestre vedvarende symptomer» (1).

\section{$\equiv$ ¿Flesteparten av brukerne har valgt å motta minimum to sesjoner i uken.»}

I seksjonens døgnenhet har vi valgt å gjøre første modul obligatorisk. Denne modulen introduserer IMR som arbeidsform, og det er også i denne modulen at brukeren setter mål for arbeidet. (1) Deretter har vi latt brukeren selv velge hvilke moduler som er aktuelle for vedkommende. Flesteparten av brukerne har valgt å motta minimum to sesjoner i uken. Mange sesjoner har blitt gjennomført på kveldsvakter.

I seksjonens dagrehabilitering har brukere fătt tilbud om IMR som gruppebehandling. Gruppen har hatt møter ukentlig og modulene har blitt gjennomført i kronologisk rekkefølge. Gruppen har bestått av to IMR-terapeuter og et varierende antall brukere.

\section{Implementeringsmetode}

Vi i prosjektgruppen har valgt selvbestemmelsesteori (Self determination theory: SDT) som teoretisk rammeverk for å forstå utfordringene som ligger i å iverksette behandlingsprogrammet IMR. Ut fra selvbestemmelsesteorien SDT forstår vi at individets autonomi er en følelse av at personens handlinger er selvbestemte, og i tråd med egne verdier. Individet er ifølge teorien styrt av både indre og ytre motivasjon, men gjennomfører i større grad egne mål når det føler seg autonomt.

Vi har erfart at brukere som har vært deltakere i behandlingsprogrammet, gjerne tar på seg oppgaver de synes er kjedelige eller ubehagelige når det er hensiktsmessig for å oppnå egne mål. Våre erfaringer er i tråd med SDT, som hevder at mennesker i større grad gjennomfører egne mål når de føler seg autonome. (6) 


\section{Brukerne definerer selv hvilke mål de vil jobbe mot}

Vi har derfor vært veldig opptatt av autonomi når vi har tatt metodikken i bruk ved vår seksjon. I praksis har dette betydd at brukerne selv har definert hvilke mål de jobber mot, og har selv bestemt hvilke aktiviteter de må gjennomføre for å nå målene sine.

\section{三 «Arbeidet med IMR skal handle om det som brukeren opplever som viktig.»}

Innledningsvis har vi ofte sagt til brukerne at arbeidet med IMR skal handle om deres mål og det som de opplever som viktig, og så lenge målene ikke er i strid med norsk lov, som for eksempel rusbruk, eller i strid med hva som er helsemessig forsvarlig, eksempelvis farlig lav kroppsmasseindeks (KMI), kan vi sammen arbeide mot målene.

Underveis i arbeidet har vi gjentatt dette budskapet. Om brukeren spør «må jeg gjøre hjemmeoppgave til neste gang» har vårt svar vært at «dette må du velge selv. Vi kan komme med en anbefaling, men dette er ditt behandlingsopplegg. Hvis du mener det er hensiktsmessig å gjøre hjemmeoppgave til neste gang, så gjør gjerne det».

\section{Ovenfra og ned eller nedenfra og opp?}

Implementeringsstrategier kan overordnet sett fordeles i to kategorier; «top down» (ovenfra og ned) og «bottom up» (nedenfra og opp) (7). Når en implementeringsstrategi er basert på «top down»-tenkning, kommer føringene for implementeringen fra et ledernivå over de ansatte. Motsatsen til dette er «bottom up»-implementering, hvor de som utøver intervensjonen også er de som bestemmer hvordan denne implementeres (8). Williams og medarbeidere (8) hevder at autonomi blant tjenesteut $\varnothing$ verne bør være sentralt om man $\varnothing$ nsker å lykkes med implementering av tilfriskningsorienterte intervensjoner.

\section{Vi har sammen formet tilbudet}


I vår seksjon har vi som utøvere av IMR fått anledning til å selv forme tilbudet. Vi har hatt tett dialog med ledere og behandlere, men vi har tatt selvstendige veivalg i hvordan metodikken har blitt iverksatt. Vi som prosjektgruppe har selv valgt at intervensjonen gis som individuell behandling $i$ den ene enheten og gruppebehandling i den andre, i samråd med brukerne. For eksempel har vi bestemt lengden på behandlingen, om behandling gis på dagvakt eller kveldsvakt, om vi er en eller to fra personalet i samtalene, i hvilken rekkefølge vi gir de ulike modulene og hvor ofte vi gir behandlingen.

\section{三 «Små og store valg har blitt tatt av oss sammen med brukerne.»}

Små og store valg i prosjektet har blitt tatt av oss som prosjektmedarbeidere sammen med brukerne. Williams og medarbeidere (8) peker på at selvstyrte hjelpere er motiverte hjelpere, noe som er i tråd med våre erfaringer fra dette prosjektet. «Bottom up»-implementering har ved vår seksjon konkret betydd at brukere og hjelpere sammen har funnet ut av hvordan metodikken skal tas i bruk og har fått frihet til å ta eget valg i prosessen.

\section{Barrierer for implementering av IMR}

Ifølge Baker og medarbeidere (9) er det viktig å identifisere barrierer når man implementerer kunnskapsbasert praksis. Vi har fors $\varnothing \mathrm{kt}$ å se for oss hvilke hindringer som gjør det vanskelig å implementere individuell mestring og tilfriskning og har laget tiltak ut fra disse hindringene. Vi har også gjort databases $\varnothing \mathrm{k}$ for å finne empiri som belyser temaet.

I forskningslitteratur har vi funnet at sentrale barrierer mot implementering av IMR er manglende tilgang på materialet, manglende lederforankring og manglende tid til å gjennomføre intervensjonen (10). Manglende enighet om hvilke verdier som skal styre arbeidet med implementeringen, kan også være en hindring (8), noe vi skriver om i neste avsnitt.

\section{Uenighet blant de ansatte kan gå ut over kvaliteten}

En barriere mot implementering kan være at helsepersonell som tar en metodikk i bruk, ikke er enige om hvilke verdier som er viktige ved metodikken. Hvis vi som utøvere ikke er enige om hva som skal vektlegges ved en arbeidsmetode, blir kvaliteten både på arbeidsformen og implementeringen lav. 
På den andre siden risikerer vi at for mye enighet tar oppmerksomheten bort fra brukernes individuelle behov og $\varnothing$ nsker (8). Vi som prosjektgruppe har vært opptatt av ikke bare «å ha de rette verdiene», men også jobbe med metodikken slik at verdiene kommer til syne. Williams og medarbeidere viser til at synlige verdier er en faktor som fremmer god implementering av behandlingsmetodikk (8).

\title{
$\equiv$ EVi har satt av tid til diskusjoner for å finne ut av hva som er viktig for oss.»
}

\begin{abstract}
Vi har satt av tid til diskusjoner, for å finne ut av hva som er viktig for oss. I denne prosessen har vi kommet frem til at vi vil arbeide ut fra brukerens $\varnothing$ nsker, men med en arbeidsform som er evidensbasert. Vi har aktivt valgt en balansegang mellom brukers medvirkningsrett over egen behandling og vårt eget $\varnothing$ nske om å benytte en empirisk fundert og strukturert metodikk.
\end{abstract}

\section{Medvirkning gir gode samtaler}

Vi opplever at bruk av individuell mestring og tilfriskning bidrar til økt likhet mellom hjelper og bruker, fordi vi som hjelpere tilfører bruker kunnskap. Kunnskap gir brukeren anledning til å gjøre informerte og veloverveide valg, noe vi mener fremmer brukermedvirkningen. Vi har tidligere $i$ denne artikkelen vist til hvordan vi i arbeidet med IMR legger vekt på at det er brukeren selv som definerer mål for innsatsen, og i stor grad selv styrere framgangen i denne.

\section{三 «Vår rolle som hjelpere har vært å tilby bistand og veiledning underveis samt å holde strukturen $\mathrm{i}$ intervensjonen.»}

Vår rolle som hjelpere har vært å tilby bistand og veiledning underveis samt å holde strukturen i intervensjonen. Vi har valgt å i liten grad sette spørsmålstegn ved brukerens mål, men isteden valgt å tematisere hvorfor et mål synes viktig og hvordan livet ville blitt annerledes hvis målet ble innfridd.

Ved å jobbe på denne måten, har vi erfart at gode samtaler om hva som oppleves som viktige livsendringer for brukeren settes i gang. Åpne spørsmål som «hva hadde vært annerledes om», «hva ville du gjort hvis», «hva må til for at», «hvordan skal du gå frem for å», har latt oss anspore brukeren til å reflektere og til å ta i bruk egne ressurser for å nå mål. 


\section{Tiltak for å øke forankringen}

Prosjektgruppens innstilling har vært at synlighet og tilgang til informasjon er viktig for å sikre en vellykket implementering. Dette er i tråd med litteratur som viser til at tilgang til manual og informasjonsmateriell er en faktor som fremmer implementering (10). Vi har gjennomført en rekke tiltak for å $\varnothing$ ke personalforankring rundt prosjektet i seksjonen.

Vi har derfor invitert eksterne forelesere med kompetanse på IMR til å holde foredrag på lokale fagseminarer, gjennomført internundervisning for ansatte og studenter, delt ut brosjyremateriale, arrangert informasjonsm øte for ledere og behandlere før oppstart av prosjektet og vært til stede i behandlingsmøter for å rette oppmerksomheten mot tilbudet.

\section{Internundervisning og quiz}

Som et supplement til eksterne foreleser, har vi også arrangert intern undervisning ved seksjonen flere ganger. Vi har i den anledning også arrangert tilfrisknings-quiz i digital form med dataprogrammet «Kahoot» og fătt gode tilbakemeldinger på dette.

\section{Tavle og manual for ansatte}

I døgnenheten har vi satt opp en IMR-tavle, hvor vi fører opp pågående IMR-løp slik at det er synlig for ansatte at IMR utøves ved seksjonen. Vi har også gjort en IMR-manual tilgjengelig på enhetens teamkontor, slik at personal som er interessert kan se i den, siden tilgang til materialet nevnes som en fremmende faktor for implementering $i$ forskning (10).

\section{Vi har utformet en teamkontrakt}

Prosjektgruppen laget en teamkontrakt ved oppstarten av prosjektet, som viste hvilke mål vi sammen skulle jobbe mot, og hvilke tiltak som måtte gjennomføres for å oppnå felles mål. Dokumentet inneholder føringer for hvem som gjør hva, og når.

\section{Personalet får veiledning}


Personalet ved vår seksjon som utøver metoden, har hatt mulighet til å få jevnlig veiledning. Veiledning fikk vi innledningsvis av IMR-terapeuter ved Crux Bergfløtt behandlingssenter. Etter at seksjonen vår fikk egne IMRterapeuter, har disse selv veiledet andre som utøver intervensjonen. Vi har erfart at veiledning har vært motiverende for å arbeide videre med metodikken, og at det er har hevet kvaliteten på intervensjonen.

Vi har tilrettelagt for at brukerne kan henvises fra individuell behandling i døgnenheten til gruppebehandling i poliklinikkens dagrehabilitering. Vår intensjon har vært at brukere kan få tilbud om IMR som individuell behandling i døgnenheten og fortsette i gruppebehandling i poliklinikkens dagrehabilitering.

\section{Tiltak rettet mot leder- og behandlergruppen}

Forskning vi har funnet rundt implementering av IMR viser at forankring på ulike ledernivå, samt en klar lederfigur i

gruppen som utøver IMR, er viktige fremmere for implementering (10).

\section{Dialog med ledergruppen}

Vi valgte derfor å gå i dialog med ledergruppen for å sikre solid forankring for metodikken. Ved at vi startet tidlig med en dialog rundt IMR som behandlingstilbud, fikk vi avklart hvilke forventninger vi hadde til hverandre. Vi tror at det å sikre forankring før vi gikk i gang med selve prosjektet har vært kritisk viktig for å lykkes med implementeringen.

\section{Samarbeid med behandlerne}

I spesialisthelsetjenesten er det også relevant å se behandlere som en utvidet del av ledergruppen, siden behandlergruppen har stor innflytelse på behandlingshensyn og valg av terapeutisk tilnærming. Vi i prosjektgruppen har formidlet at vi ønsker å samarbeide med behandlere om bruken av IMR, slik at metoden ikke blir et konkurrerende tilbud i forhold til behandleres samtaleterapeutiske intervensjoner. 
Ved å dokumentere fra IMR-sesjonene i DIPS (enhetens kliniske dokumentasjonssystem) har vi gjort metoden gjennomsiktig slik at behandlere og andre i teamet rundt brukerne kan følge løpet. Vi har også registrert en såkalt «frase» i DIPS. Frasen fungerer som en hjelpetekst for å dokumentere IMR-sesjoner. Frasen inneholder navnet på modulene i metoden (1), og hensikten med frasen er å gjøre det lettere for IMR-terapeuten å dokumentere intervensjonen.

\section{Evaluering av implementeringsstrategien}

For å kunne evaluere hvorvidt vi har lyktes med implementering av IMR, har vi innhentet data både i form av antall IMR-sesjoner som er utført og kvalitative intervju med brukerne og personalet som har brukt metodikken.

Vi som har utøvd intervensjonen har ført anonymisert regnskap over antall utførte sesjoner og har jevnlig oppdatert et sentralt anonymisert regnskap. Dette har gitt prosjektgruppen mulighet til å måle progresjon opp mot et kvantitativt implementeringsmål.

\section{三 «Siden høsten 2018 har vi gjennomført 200 sesjoner.»}

Siden høsten 2018 har vi gjennomført 200 sesjoner IMR. Av disse er 50 gruppesesjoner gjennomført ved poliklinikkens dagrehabilitering og 150 individuelle sesjoner i døgnenheten.

Vi har også evaluert IMR-tilbudet i seksjonen ved hjelp av åpne intervjuer med seks brukere av tilbudet. Vi har ikke innhentet samtykke fra brukerne til at data fra intervjuene kan brukes til annet enn intern kvalitetskontroll innad i seksjonen. Vi har også evaluert tilbudet innad i prosjektgruppen. Erfaringer fra brukerne, personalet og talldata rundt antall sesjoner sammenfattet vi i en intern prosjektrapport, som ble sendt til ledergruppen.

\section{Konklusjon}

Vår seksjon valgte våren 2019 å satse på Individuell mestring og tilfriskning som en fast del av vårt behandlingstilbud. Satsingen ble nedfelt i seksjonens handlingsplan og flere ansatte ble sendt på kurs. Per i dag har vi tre godkjente IMRterapeuter, som i tillegg til å utøve intervensjonen også veileder andre ansatte i metodikken. 


\section{$\equiv$ «Resultatene fra evalueringen tyder på at vi har lyktes med å implementere IMR i vår seksjon.»}

Vi hadde flere målsettinger da vi igangsatte prosjektet. Vi $\emptyset n s k e t$ å tilby brukerne våre en intervensjon hvor brukermedvirkning som verdi var klart kommunisert. Vi $\varnothing$ nsket også å arbeide aktivt med å forankre metoden i lederog personalgruppen og gjøre IMR som metodikk synlig og tilgjengelig for både ansatte og brukere. Antallet sesjoner vi har gjennomført, og resultatene fra evalueringen med brukere og ansatte, tyder på at vi har lyktes med å implementere IMR i vår seksjon.

I arbeidet med dette fagprosjektet har vi kun benyttet anonymiserte data og har fătt tilrådning fra personvernombudet ved Ullevål universitetssykehus til publikasjon.

\section{Referanser}

1. IMR-nettverket. IMR-manual og app. IMR-nettverket; 2019. Tilgjengelig fra: https://imr.lillestrom.kommune.no/ (nedlastet 14.09.2020).

2. Mueser KT, Corrigan PW, Hilton DW, Tanzman B, Schaub A, Gingerich S, et al. Illness management and recovery: a review of the research. Psychiatr Servi. 2002;53(10):1272-84.

3. Salyers MP, Godfrey JL, McGuire AB, Gearhart T, Rollins AL, Boyle C. Implementing the illness management and recovery program for consumers with severe mental illness. Psychiatr Servi. 2009;60(4):483-90.

4. Helsedirektoratet. Nasjonal faglig retningslinje for utredning, behandling og oppfølging av personer med psykoselidelser. Oslo: Helsedirektoratet; 2013. IS-1957.

5. Boutillier CL, Leamy M, Bird VJ, Davidson L, Williams J, Slade M. What does recovery mean in practice? A qualitative analysis of international recovery-oriented practice guidance. Psychiatr Servi. 2011;62(12):1470-6.

6. Ryan RM, Deci EL. Self-determination theory: Basic psychological needs in motivation, development, and wellness. New York: Guilford Press; 2018. 
7. Sabatier PA. Top-down and bottom-up approaches to implementation research: a critical analysis and suggested synthesis. Journal of Public Policy. 1986;6(1):21-48.

8. Williams VC, Deane FP, Oades LG, Crowe TP, Ciarrochi J, Andresen R. Enhancing recovery orientation within mental health services: expanding the utility of values. $\mathrm{J} \mathrm{MH}$ Training, Ed and Practice. 2016;11(1):23-32.

9. Baker R, Camosso-Stefinovic J, Gillies C, Shaw EJ, Cheater F, Flottorp S, et al. Tailored interventions to overcome identified barriers to change: effects on professional practice and health care outcomes. Cochrane Database of Syst Rev. 2010;17(3):CDoo5470.

10. Salyers M, Rollins A, McGuire A, Gearhart T. Barriers and facilitators in implementing illness management and recovery for consumers with severe mental illness: trainee perspectives. Adm Policy Ment Health. 2009;36(2):102-11. 